\title{
Saltmarsh Caterpillar, Estigmene acrea (Drury) (Insecta: Lepidoptera: Arctiidae) 1
}

John L. Capinera ${ }^{2}$

\section{Distribution}

The saltmarsh caterpillar, Estigmene acrea (Drury), is a native insect found throughout the United States. Its distribution extends to Central America, and in Canada it has damaged crops in Ontario and Quebec. As a pest, it is most common in the southern United States, particularly the southwest.

\section{Description and Life Cycle}

A generation can be completed in 35 to 40 days under ideal conditions, but most reports from the field suggest about six weeks between generations. The number of generations per year is estimated at one in the northern states to three to four in the south. Overwintering reportedly occurs in the mature larval stage, with pupation early in the spring. Saltmarsh caterpillars usually are infrequent early in the season, but may attain high numbers by autumn.

\section{Eggs}

The eggs are nearly spherical in shape, and measure about $0.6 \mathrm{~mm}$ in diameter. Initially they are

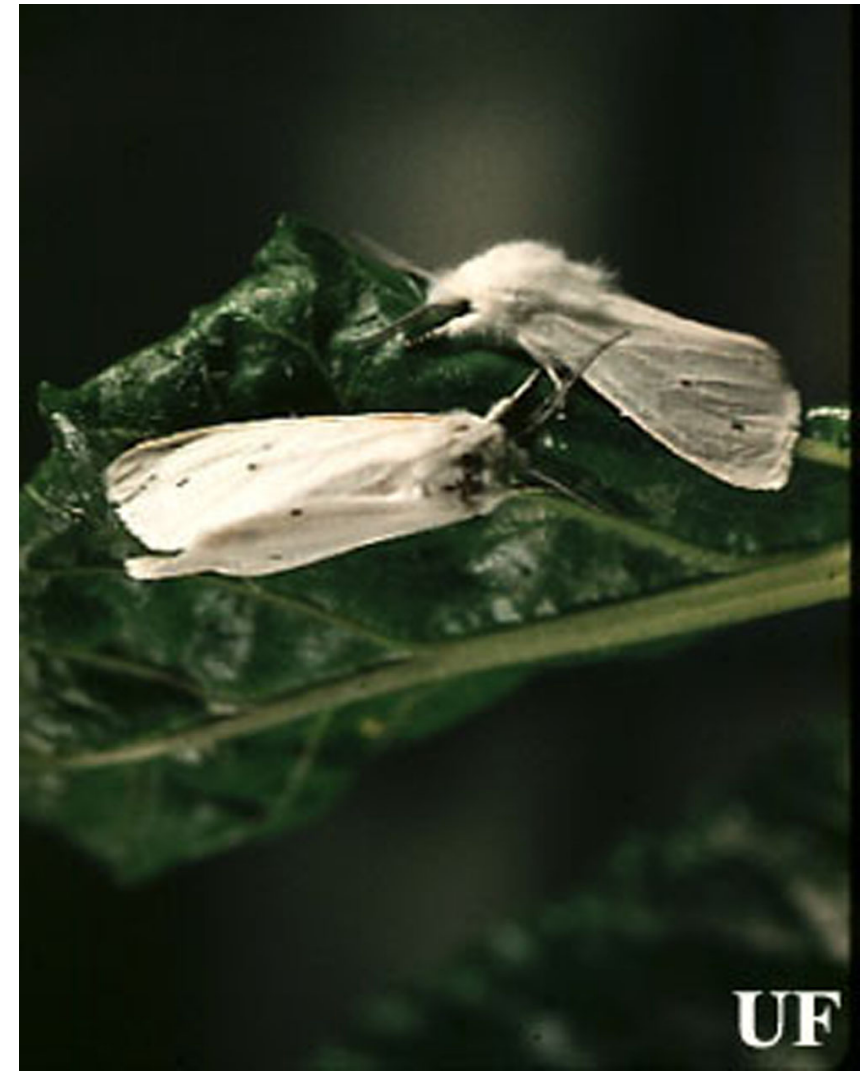

Figure 1. Adult saltmarsh caterpillars, Estigmene acrea (Drury). Credits: John L. Capinera, University of Florida

1. This document is EENY-218, one of a series of Featured Creatures from the Entomology and Nematology Department, Florida Cooperative Extension Service, Institute of Food and Agricultural Sciences, University of Florida. Published: July 2001. This document is also available on Featured Creatures Website at http://creatures.ifas.ufl.edu. Please visit the EDIS Website at http://edis.ifas.ufl.edu. Additional information on these organisms, including many color photographs, is available at the Entomology and Nematology Department Website at http://entnemdept.ifas.ufl.edu/. 2. John L. Capinera, department chairman/professor, Entomology and Nematology Department, University of Florida, Gainesville, FL.

The Institute of Food and Agricultural Sciences (IFAS) is an Equal Employment Opportunity - Affirmative Action Employer authorized to provide research, educational information and other services only to individuals and institutions that function without regard to race, creed, color, religion, age, disability, sex, sexual orientation, marital status, national origin, political opinions or affiliations. For information on obtaining other extension publications, contact your county Cooperative Extension Service office. Florida Cooperative Extension Service / Institute of Food and Agricultural Sciences / University of Florida / Larry R. Arrington, Interim Dean 
yellow, but soon become grayish in color. Females commonly produce 400 to 1000 eggs in one or more clusters. It is not unusual to find a single egg cluster containing 1200 eggs. Eggs hatch in four to five days.

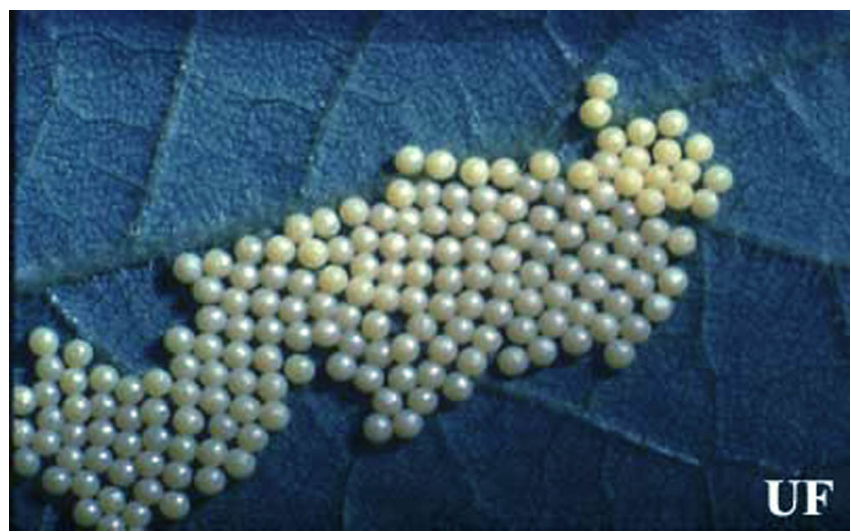

Figure 2. Eggs of the saltmarsh caterpillar, Estigmene acrea (Drury). Credits: John L. Capinera, University of Florida

\section{Larvae}

There are five to seven instars. The following description is based on Hinds (1904), who observed five instars in Texas. Upon hatching the larvae are about $2 \mathrm{~mm}$ in length, brown in color, and bear numerous long over the entire length of the body. During this stage, and the subsequent instar, larvae feed gregariously on the lower leaf surface, usually failing to eat entirely through the leaf. Larvae attain a length of about $10 \mathrm{~mm}$ during the first instar. Second instars display longitudinal stripes, usually brown, yellowish, and white, and the body hairs become darker. Larvae attain a length of about $15 \mathrm{~mm}$. During the third instar, larvae become darker, but a consistent color pattern is not apparent. Larvae attain a length of about $30 \mathrm{~mm}$. In the fourth and fifth instars, larvae maintain the same general appearance as earlier stages, but grow to a length of about 45 and $55 \mathrm{~mm}$, respectively. Larvae usually are dark, but sometimes are yellowish brown or straw colored. The larvae are marked by long body hairs, and these also vary in color from cream or grayish to yellowish brown to dark brown. Although they are decidedly hairy, the hairs are not as dense or as stiff as those found in woollybear larvae. Duration of larval development was 24 to 37 days. In contrast, Young and Sifuentes (1959) and Capinera (1978b) reported six instars in Mexico and Colorado, respectively. Development time of the six instars was about 3,2, 2,
2,3 , and 8 days, respectively, for a larval period of 20 to 22 days, depending on diet. However, some studies have reported longer larval periods, up to about 45 days.

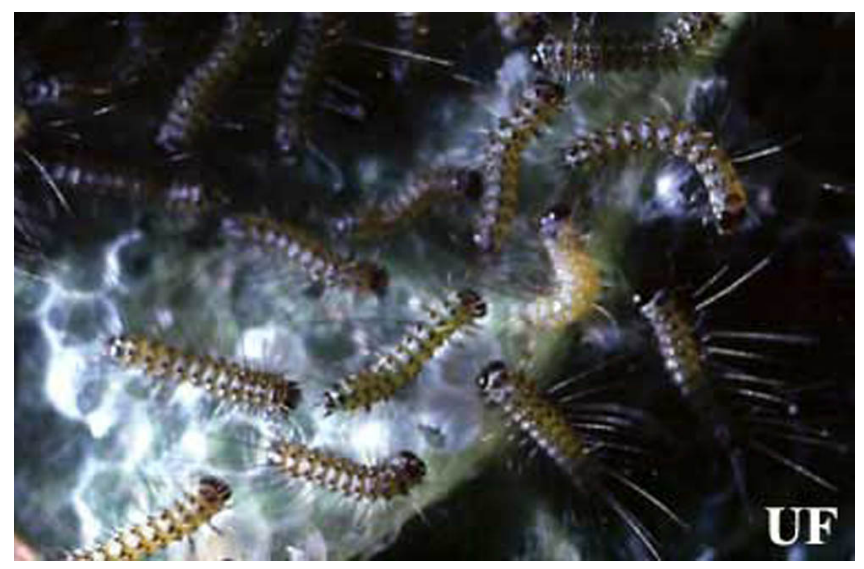

Figure 3. Aggregation of young saltmarsh caterpillars, Estigmene acrea (Drury). Credits: John L. Capinera, University of Florida

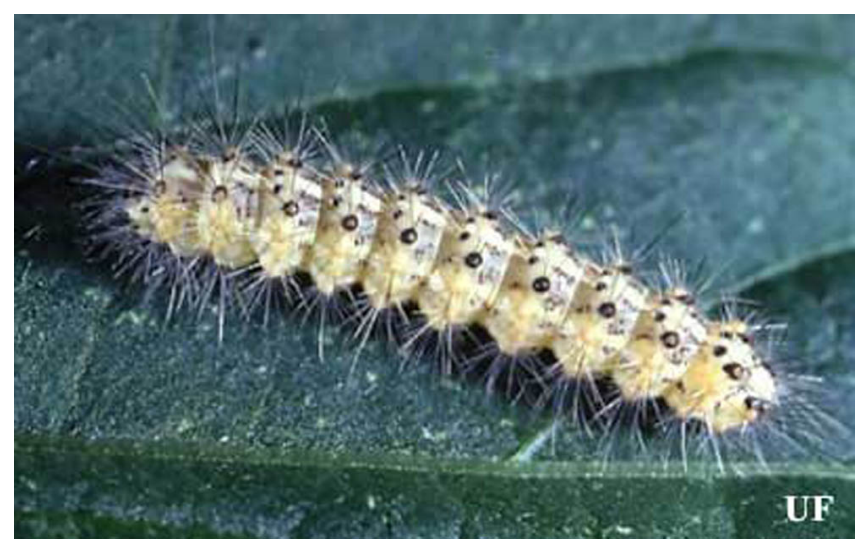

Figure 4. Young saltmarsh caterpillar, Estigmene acrea (Drury). Credits: John L. Capinera, University of Florida

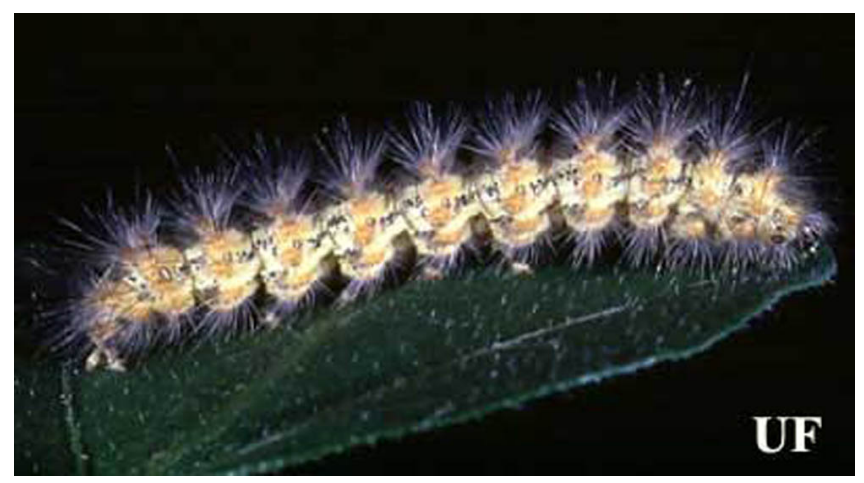

Figure 5. Intermediate stage of the saltmarsh caterpillar, Estigmene acrea (Drury). Credits: John L. Capinera, University of Florida

Larvae are active dispersers, a habit that is relatively uncommon among caterpillars. Most 


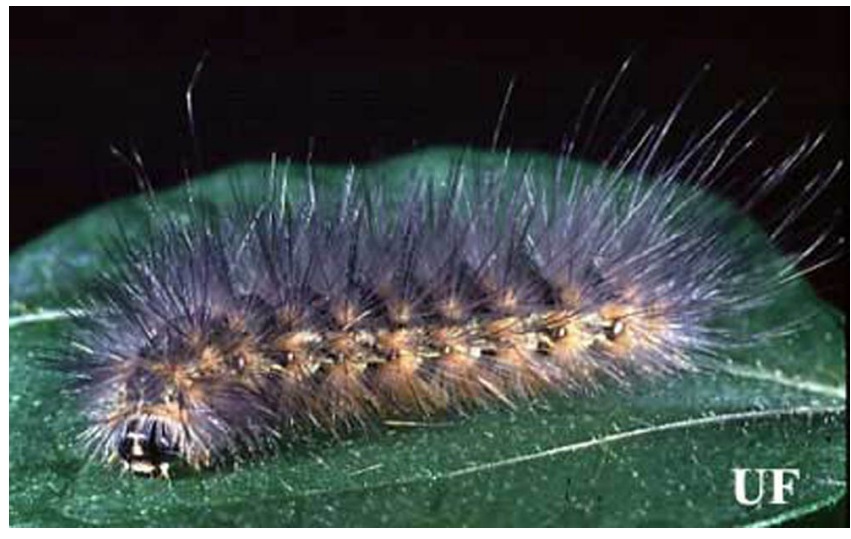

Figure 6. Mature saltmarsh caterpillar, Estigmene acrea (Drury). Credits: John L. Capinera, University of Florida

commonly, late instar larvae are found individually or in large numbers ambling over the soil, searching for suitable food. Damage to margins of crop fields often occurs as such larvae desert drying weeds for irrigated crops. Stracener (1931) reported that young larvae drop readily from plants when disturbed, spin a strand of silk, and are blown considerable distances by wind. Frequency of distribution by wind is unknown.

\section{Pupae}

Pupation occurs on the soil among leaf debris, in a thin cocoon formed from silken hairs interwoven with caterpillar body hairs. The dark brown pupae measures about $30 \mathrm{~mm}$ in length. Duration of the pupal stage is about 12 to 14 days.

\section{Adult}

Adults are fairly large moths, measuring 3.5 to $4.5 \mathrm{~cm}$ in wingspan, and are distinctive in appearance. They are predominantly white in color, although generally the wings bear numerous, small, irregular black spots. The hind wings of the male are yellow; those of the female are white. The underside of the male's front wings may also be tinted yellowish. Most of the abdominal segments are yellow, and bear a series of large black spots dorsally. Mating occurs the evening following emergence, and egg deposition the next evening. Females usually live only four to five days, but may produce more than one cluster of eggs.

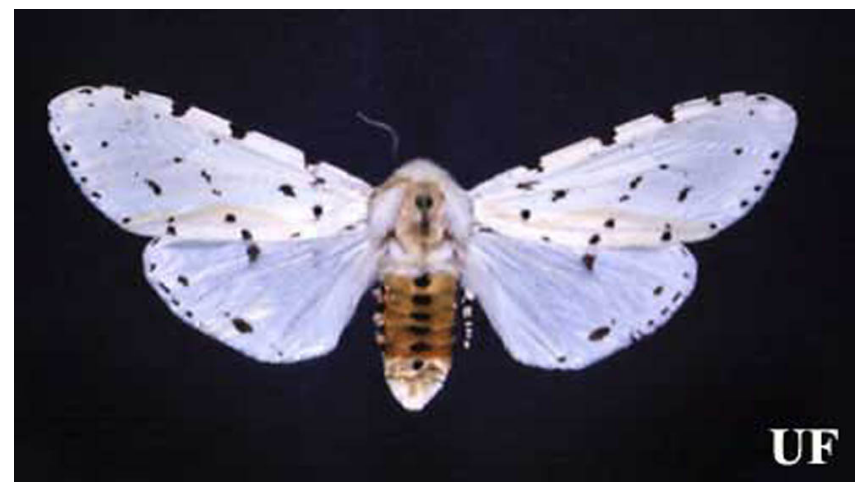

Figure 7. Adult female saltmarsh caterpillar, Estigmene acrea (Drury). Credits: John L. Capinera, University of Florida

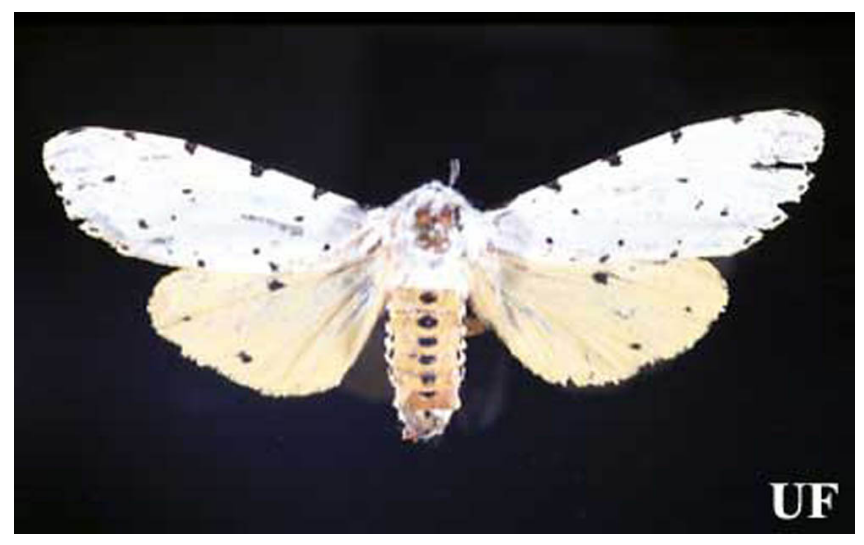

Figure 8. Adult male saltmarsh caterpillar, Estigmene acrea (Drury). Credits: John L. Capinera, University of Florida

\section{Host Plants}

Saltmarsh caterpillar's peculiar common name is derived from initial description as a pest of salt-grass hay grown in the vicinity of Boston. This is an anomaly, and despite the wide host range of this insect, grasses are not particularly preferred. Broadleaf weeds are the normal host plants, but larvae commonly disperse from these late in the growing season to damage vegetable and field crops. Vegetables injured include asparagus, bean, beet, cabbage, carrot, celery, corn, lettuce, onion, pea, tomato, turnip, and probably others. Field crops damaged are alfalfa, clover, cotton, soybean, sugarbeet, and tobacco. The favored weed host seems to be pigweed, Amaranthus spp., but many others may be consumed, including anglepod, Gonolobus sp.; sicklepod, Cassia tora; dog fennel, Eupatorium capillifolium; ground cherry, Physalis spp.; and mallow, Anoda sp. 


\section{Damage}

Larvae are defoliators. Young larvae feed gregariously and skeletonize foliage. Older larvae are solitary and eat large holes in leaf tissue. Older larvae may disperse long distances in search of food, sometimes moving in large numbers. Commonly this is associated with maturation of cotton or weeds in the autumn. Thus, these caterpillars tend to be damaging to fall-planted crops. Foliage consumption at least doubles with each succeeding instar, and mature larvae can consume over $13 \mathrm{sq} \mathrm{cm}$ of thick-leaved foliage, such as sugarbeet, daily (Capinera 1978). Capinera et al. (1987) measured bean foliage consumption by each instar, and recorded over $400 \mathrm{sq} \mathrm{cm}$ of foliage consumed during the life of a caterpillar. Further, they estimated that one to 1.5 mature caterpillars per plant could inflict $20 \%$ defoliation to a bean plant, a level adequate to cause yield loss.

\section{Natural Enemies}

Saltmarsh caterpillar larvae frequently are parasitized, particularly by tachinids (Diptera: Tachinidae). In Arizona, the most common parasitoids were Exorista mellea (Walker) and Leschenaultia adusta (Loew), but Gymnocarcelia ricinorum Townsend and Lespesia archippivora (Riley) were also observed (Taylor 1954). Jackson et al. (1970) documented the biology and importance of L. adusta. Arnaud (1978) reports additional species of tachinids associated with saltmarsh caterpillar.

Hymenopteran parasitoids are known from both the larval and egg stages (Taylor 1954, Taylor and Stern 1971), and include Apanteles diacrisiae Gahan (Braconidae); Therion fuscipenne (Norton), T. morio (Fabricius), Casinaria genuina (Norton), Hyposoter rivalis (Cresson) (all Ichneumonidae); Psychophagus omnivorus (Walker), Tritneptis hemerocampae Vierick (both Pteromalidae); Anastatus reduvii (Howard) (Eupelmidae); and Trichogramma semifumatum (Perkins) (Trichogrammatidae).

A cytoplasmic polyhedrosis virus is known (Langridge 1983), but there are little data on importance.
General predators such as lady beetles (Coleoptera: Coccinellidae), softwinged flower beetles (Coleoptera: Melydridae), and assassin bugs (Hemiptera: Reduviidae) prey on these caterpillars, but are not thought to be very important in population regulation (Young and Sifuentes 1959).

\section{Management}

Insecticides are commonly used to suppress saltmarsh caterpillars if they become abundant in vegetable crops. Baits are not effective. Most damage occurs at field margins as larvae disperse into crops from nearby senescent vegetation. Both chemical insecticides and Bacillus thuringiensis are recommended. Physical barriers, including ditches or trenches with steep sides, can be used to interrupt invasion of crops by caterpillars.

For more management information see:

Insect Management Guide for Field Crops (http://edis.ifas.ufl.edu/TOPIC_GUIDE_IG_ Field_Crops_and_Pastures)

Insect Management Guide for Vegetables (http://edis.ifas.ufl.edu/TOPIC_GUIDE_IG_ Vegetables)

\section{Selected References}

Arnaud, Jr., P.H. 1978. A host-parasite catalog of North American Tachinidae (Diptera). USDA Misc. Publ. 1319. 860 pp.

Capinera, J.L. 1978. Consumption of sugarbeet foliage by the saltmarsh caterpillar. J. Econ. Entomol. 71:661-663.

Capinera J.L. 2001. Handbook of Vegetable Pests. Academic Press, San Diego. 729 pp.

Capinera, J.L., D.R. Horton, N.D. Epsky, and P.L. Chapman. 1987. Effects of plant density and late- season defoliation on yield of field beans. Environ. Entomol. 16:274-280.

Jackson, C.G., D.E. Bryan, G.D. Butler, Jr., and R. Patana. 1970. Development, fecundity, and longevity of Leschenaultia adusta, a tachinid parasite of the salt-marsh caterpillar. J. Econ. Entomol. 63:1396-1397. 
Langridge, W.H.R. 1983. Characterization of a cytoplasmic polyhedrosis virus from Estigmene acrea (Lepidoptera). J. Invertebr. Pathol. 42:259-263.

Stracener, C.L. 1931. Economic importance of the salt-marsh caterpillar (Estigmene acraea Drury) in Louisiana. J. Econ. Entomol. 24:835-838.

Taylor, E.A. 1954. Parasitization of the salt-marsh caterpillar in Arizona. J. Econ. Entomol. 47:525- 530 .

Taylor, T.A. and V.M. Stern. 1971.

Host-preference studies with the egg parasite Trichogramma semifumatum (Hymenoptera: Trichogrammatidae). Ann. Entomol. Soc. Am. 64:1381-1390.

Young, W.R. and J.A. Sifuentes. 1959. Biological and control studies on Estigmene acrea (Drury), a pest of corn in the Yaqui Valley, Sonora, Mexico. J. Econ. Entomol. 52:1109-1111. 